\title{
SCAFFOLDING FOR CONTENT KNOWLEDGE OF HOME LANGUAGE LEARNING BY COLLABORATIVE ONLINE DICTIONARIES
}

Michele F.van der Merwe

University of Stellenbosch

\begin{abstract}
Dictionaries provide language learners and language users with lexical information and serve as mediating, supporting tools during language learning. Online dictionaries in the form of wikis can be assembled by dictionary users themselves. Their construction (selection of terminology and content of descriptions) in the home language class facilitates learning. During the learning process, dictionary users (university students, in this case) construct new knowledge and meaning based on their own experiences and motivations. The article is based on reflective feedback from a dictionary project undertaken in a faculty of education at a university in the Western Cape. Senior home language students were guided to collaboratively develop an online dictionary of language for specific purposes, thereby improving their communicative skills in addition to their lexical and academic subject vocabulary knowledge. Technology-enhanced language learning was mediated through a task-based language learning process. Data were generated by means of questionnaires that presented students with an opportunity to critically reflect on the use of technology as well as their own construction of knowledge by describing different scaffolding strategies in the selection of vocabulary employed during the process of wiki compilation. Positive results from the study highlight the benefits of appropriate, collaborative use of technology during language learning in a home language class. A new scaffolding model for learning content knowledge in the home language in a technology-enabled environment is proposed in the article.
\end{abstract}

Keywords: home language learning; collaborative online learning; online dictionaries; wiki compilation; content knowledge; scaffolding model

\section{INTRODUCTION}

The pedagogical value of electronic dictionaries is acknowledged widely (Gouws, 2016; Lew, 2010; Nkomo \& Madiba, 2011; Taljard, 2015). According to Lew (2010: 291), research provides evidence that the main consultation needs of dictionary users, be they on different levels of language proficiency, of different mother tongues or nationality, would still relate to the meaning of words. Lew (2010: 291) acknowledges that users have different consultation needs that are dependent on personal preferences, but primarily on the specific task and the circumstances of consultation. Lew (2010: 291) stresses that lexicographers should give their most careful attention to the treatment of meaning, so that they can satisfy the primary need of dictionary users. Traditional printed dictionaries have used a repertoire of devices for 
representing meaning in paper dictionaries, most of them having to do with words. As electronic dictionaries grow in importance, this repertoire can be extended.

Aslan (2016: 1) regards vocabulary as one of the most important elements while learning a new language, as learning a new language takes place with acquisition of new words. Unknown words pose obstacles while understanding a language. In order to eliminate these obstacles, vocabulary enrichment is needed. Aslan (2016: 1) views dictionaries undoubtedly as one of the most important sources of reference. Dictionaries, as one of the fundamental references, have long been one of the most important sources helping students by including words, phrases, terms or idioms, correct ways of writing, vocalisation, and assistance with proper usage. His view could also be applied to home language speakers, especially when it comes to the acquisition of terms, albeit in their home language. Nkomo and Madiba (2011: 147) define terminology as special subject field vocabulary. They describe modern practices where specialised subject experts identify difficult concepts and explain them in glossaries, which are either published as independent texts or integrated into textbooks.

Taljard (2015: 389) makes the assumption that the majority of South African students are exposed to a tertiary education system where the language of teaching and learning is not their strongest language (i.e., their L1) as she reports on the establishment of a multilingual, open education resource term bank by the University of Pretoria and the University of Cape Town. The aim (Taljard, 2015: 389) is to create a terminological tool which can serve as pedagogical support tool to South African students.

She envisages that, in terms of Bergenholtz and Bothma's (2011: 61, 62) function theory on dictionaries, that the open education resource term bank will be used in cognitive and communicative situations. Bergenholtz and Bothma (2011: 6,62) describe cognitive situations as knowledge-seeking situations which are unrelated to specific usage situations such as text reception. Within a cognitive situation, the user simply wants to find knowledge, which can be stored for later use. Term banks are listed as one of the most commonly used tools in these situations. Communicative situations deal with problems or doubts that the user may have regarding the process of oral or written communication, and with issues such as text reception, text production, translation and text correction, of which the first three are possibly the most important in their specific usage situation (Taljard, 2015: 589).

The Faculty of Education at the University of Stellenbosch has started the MobiLex project (Van der Merwe, 2017, 2018), an LSP (languages for specific purposes) dictionary in Afrikaans, isiXhosa and English on a mobile phone. MobiLex provides terminology, definitions and translation equivalents in all three languages. The purpose of the dictionary is to provide cognitive and communicative support to undergraduate students. Cognitive support is provided with definitions of subject concepts in students' L1, whereas communicative support is provided with translation equivalents of terms as well as definitions in the L2 and L3.

Afrikaans home language students in the BEd programme had to compile their own LSP dictionaries in preparation for the compilation of MobiLex. The aims of the project were for students to develop academic subject vocabulary to ensure success in learning content knowledge, as well as to promote the long-term retention of such vocabulary. For the lecturer/researcher, the purpose was to gain insight into the collaborative processes of compiling an LSP dictionary in the home language. 
The task of compiling a dictionary online was conducted by involving senior pre-service teachers in a communicative and collaborative way in a language learning process. For this, technological tools such as wikis were used collaboratively to generate content for a dictionary. A wiki was explored as a pedagogical tool in the home language class during the language learning process. Learning opportunities arise when students are more than mere information processors, but can learn within a complex and culturally situated setting. In such a setting, they actively participate in the learning process. This socially situated constructivist approach is in line with several learning theories (e.g., Vygotsky).

This project is described within the setting of subject-specific language, namely the Afrikaans language teaching class. In using a wiki as a tool to integrate technology during the process of language learning, this e-learning project could be seen as creative and innovative. A wiki can be defined as an activity module for which participants need to collaborate in order to create a web page. It may be undertaken collaboratively or individually. By working collaboratively, participants are able to see and edit all the contributions and are able to edit such contributions. During the project, the students were expected to compile terms for the LSP dictionary individually and they could edit individually, but they had access to all the terms compiled by their peers.

The collaborative project was culture-specific according to sociocultural theory, as all the students involved were home language speakers of Afrikaans. Task-based language learning of subject-related concepts took place within the communicative approach followed by the researcher/facilitator of the project. The uniqueness of the study lies in the emphasis on scaffolding in home language learning.

\section{COLLABORATIVE COMPILATION OF AN LSP DICTIONARY IN WIKI FORMAT}

The objectives of the task-based dictionary project were twofold: to use a curriculum-directed process to improve the academic and concept literacy of Afrikaans language teaching students, and to promote long-term retention of subject vocabulary. Academic and concept literacy forms part of the set of pedagogical content knowledge skills of language teaching students.

Pedagogical content knowledge (generally known as PCK) plays an important role in teacher expertise. Schulman (1986: 9) defines PCK as 'the most useful forms of presentation of those ideas, the most powerful analogies, illustrations, examples, explanations and demonstrationsin a word, the ways of presenting and formulating the subject that make it comprehensible to others'. Referring to the definition of PCK, it may be deduced that skills practised by means of compiling glossaries, namely the presentation of ideas, the analogies, illustrations, examples, explanations and demonstrations, as well as the formulation of terminology, would advance students' academic and cognitive skills. According to Schulman (1987: 8), PCK represents the blending of content and pedagogy into an understanding of how particular topics, problems or issues are organised, represented and adapted to the diverse interests and abilities of learners, as well as how they are presented for instruction. In the compilation of a dictionary, students' skills are practised in the blending of content and pedagogy, with the choice of how to organise, present and to adapt terminology to the level and abilities of the peer group. 
Richardson (2001: 904) describes PCK in language teaching as: 'what teachers need to know about what they teach (including what they know about the language itself) and constitutes knowledge that would not be shared with teachers of other subject areas'. In relation to what teachers need to know, it deals with their knowledge of the subject, including formal aspects of language (in this case Afrikaans), for example syntax, phonology, grammar, written and spoken language use, and comprehension, as well as discourse. In accordance with teaching formal aspects of the language, knowledge of subject matter corresponds closely to the materials that teachers have to generate. Adequate knowledge includes knowledge of vocabulary, text structure, sentence formulation and cohesion. With the compilation of a dictionary in the format of a wiki, students' vocabulary, text structure, sentence formulation and cohesion in the writing of definitions are practised.

According to the Curriculum and Assessment Policy Statement (CAPS) for Afrikaans Home Language (Department of Basic Education, 2011), dictionaries form part of the core material of prescribed books in schools. Van der Merwe (2009: 303, 310) describes the educational value of dictionaries, as well as the very important role of teachers in establishing a dictionary culture in schools. Understanding the concept of an LSP dictionary is linked with the school language curriculum in South Africa, in which dictionaries are viewed as reference works in the classroom, where dictionaries have a pivotal role to play in the development of vocabulary. Dictionaries are important pedagogical tools to be used in teaching vocabulary at school, and teachers should be able to make use of dictionaries in the language teaching process in a sound and systematic way, as part of their pedagogy. By gaining an improved conceptualisation of dictionaries, pre-service teachers should have a better comprehension of the important role of dictionaries in the pedagogical process, as well as in the teaching of reference skills.

Technology is used in the learning process during the conceptualisation of a dictionary in a wiki. This is in accordance with the psychological theory of social constructivism (Fosnot, 1996: 10), in which knowledge is mediated as temporary, developing, non-objective, internally constructed, and socially and culturally mediated. One of the approaches to teaching that makes provision for construction of meaning according to an experience is Kolb's model of experiential learning. Kolb (in Sims \& Sims, 1995: 6) describes four phases of the learning cycle through which individuals move to learn concepts effectively and to apply knowledge. The four phases of experiential learning are concrete experience, reflective observation, abstract conceptualisation and active experimentation. Experiential learning takes place in the compilation of a dictionary in a wiki, because students experience it concretely, observe reflectively, conceptualise abstractly and experiment actively with words. Compiling a dictionary in a wiki thus fits into the constructivist model for teaching followed in the module for Afrikaans language teaching. Scaffolding of the language learning process occurs while compiling a dictionary. The process is further elaborated on in the next section.

\section{SCAFFOLDING IN SOCIAL CONSTRUCTIVISM DURING THE PROCESS OF LANGUAGE LEARNING}

Carstens (2016: 1) explores the notion of scaffolding in language learning with reference to Van Lier's (2004) and Walqui's (2006) socioculturally embedded strategies for improving the performance of students' learning of subject content in their second language, namely, modelling, bridging, building schema, contextualisation, representing text and developing metacognition. According to Carstens (2016: 3), the notion of scaffolding has its roots in sociocultural theory (Vygotsky, 1978), where language is the main vehicle of thought and 
starts as dialogue and social interaction, which in turn facilitate learning and development. All learning is co-constructed through processes of apprenticeship and internalisation, and thus skills and knowledge are transformed from the social to the cognitive. The Vygotskyan zone of proximal development refers to the distance between independent problem-solving and potential development under adult guidance or in collaboration with more competent peers (Carstens, 2016: 3).

In compiling a dictionary wiki, students had to solve problems regarding lemmatisation of terms, as well as defining of terms, in collaboration with peers, thus working according to sociocultural theory. Students had to construct their own knowledge during the learning process, and the lecturer acted as a facilitator of knowledge.

The author would like to propose an alternative model for how shifts in agency may occur during the process of scaffolding for home language learning during the learning process of content knowledge, as was found during the process of compiling the wiki. This fourquadrant model is represented in Figure 1.

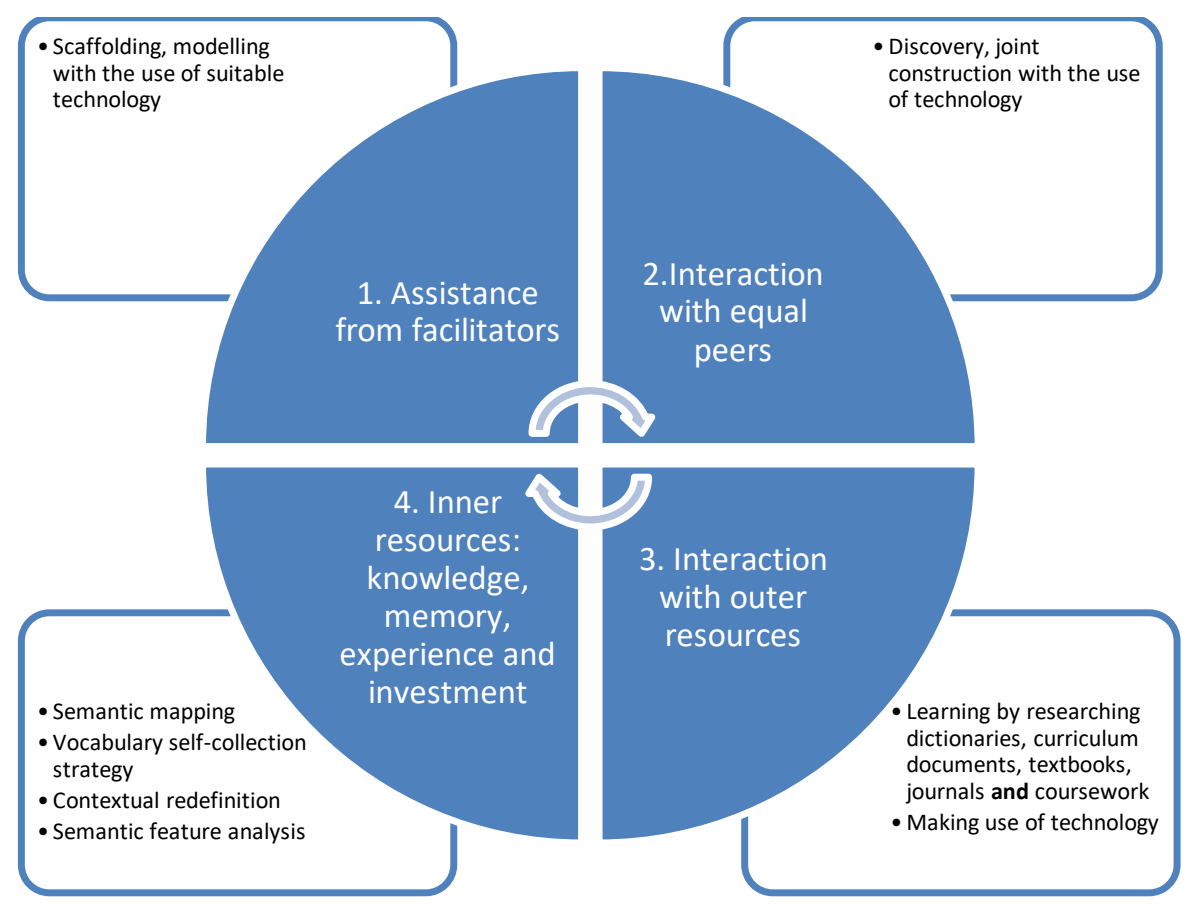

Figure 1: Schematic representation of scaffolding model for developing content knowledge for home language learners in a technology-enabled environment

The top left quadrant (1) represents the canonical understanding of scaffolding, namely, support by more experienced peers or teachers using scaffolds such as textual models in suitable technology. During the compilation of the dictionary wiki, the involved lecturer acted as a facilitator of knowledge by modelling dictionary entries on a wiki page. The top right quadrant (2) represents support by equals, which is typically collaborative. Such collaboration includes learning new words, terms, concepts and meanings. The bottom right quadrant (3) focuses on making use of outer resources available to students, namely, dictionary articles, journals and class notes. Since the students were home language speakers, they tended to be more independent learners and they enjoyed making use of other resources that are available on the internet. The bottom left quadrant (4) represents the individual's internalisation of scaffolding through making use of certain strategies for vocabulary 
development, semantic mapping, vocabulary self-collection strategy, contextual redefinition and semantic feature analysis. The third and fourth quadrants entail the development of cognitive and metacognitive structures that facilitate learner autonomy. My changes to Van Lier's third and fourth quadrants could be substantiated by reflection on the use of strategies by students involved in the dictionary wiki project. Strategies to develop academic vocabulary are discussed in the next section of the paper. Students were also asked to reflect on their use of these strategies, as reported in the following section.

\section{STRATEGIES TO DEVELOP THE ACADEMIC VOCABULARY OF STUDENTS IN LANGUAGE LEARNING}

Research shows that students' word knowledge is linked to academic success (Antonacci \& O'Callaghan, 2011: 10). Academic vocabulary (Antonacci \& O'Callaghan, 2011: 11) refers to the words associated with content knowledge. Within every discipline, there is a specific set of words that represents its concepts and processes. These words are conceptually more complex than everyday language; therefore, they are more difficult to learn. A student's depth of word knowledge within a discipline, or academic vocabulary, relates to success in that subject. To learn specialised words, such as the vocabulary of science, students must know the content associated with the words (Antonacci \& O'Callaghan, 2011: 11).

Antonacci and O'Callaghan (2011: 12) describe five strategies to develop academic literacy, namely: semantic mapping; vocabulary self-collection strategy (VSS) to promote wordconsciousness; contextual redefinition; semantic feature analysis (SFA); and list-group-label. The first four strategies are explored in this article, with reference to feedback by students on their strategies to compile the dictionary wiki. This is reported on in the section on results of students' reflections.

Semantic maps (Heimlich \& Pittelman, 1986: 10) are graphic displays of word meaning that offer students a visual presentation of how words and concepts are related through a network of organised knowledge. The use of semantic maps as instructional tools provides students with a deepening understanding of words, including their concept knowledge, relationships to other words and multiple meanings. Semantic maps provided a usable tool for pre-service teachers in the compilation of a dictionary wiki.

Word-consciousness refers to having an interest in and awareness of words, whereby students would deliberately think about the terms that they encounter in the course and what they mean. If students read terms in their coursework and understand them, they would be motivated to feel that it is necessary to know these terms for the sake of subject knowledge. According to Antonacci \& O'Callaghan (2011: 26), the purpose of VSS is to motivate students to learn new words by promoting the long-term acquisition and development of the vocabularies of academic disciplines, with the goal of integrating new content words into students' working vocabularies. The primary purpose of VSS is to deepen students' understanding of words, promote their interest in new words, and offer them a strategy to identify and learn new and fascinating words (Antonacci \& O'Callaghan, 2011: 26). With VSS, students were given a handy tool to use during the compilation of a dictionary wiki.

Contextual redefinition or using clues as a word-learning strategy is one of the most important strategies (Antonacci \& O'Callaghan, 2011: 32) to foster students' independence in word learning. To use context clues, students are directed to look for clues within the word and the sentence or surrounding sentences. Teaching students to use context clues while they 
are reading will help them to infer meanings while they are reading, but the context alone does not lead to a deep understanding of the word. Additional tools, such as dictionaries and other references, are necessary to learn more complete meanings of a word. Pre-service teachers made use of contextual redefinition, as well as reference works, during the compilation of the dictionary wiki.

The primary purpose of SFA (Antonacci \& O'Callaghan, 2011:38) is to increase students' academic vocabulary through the use of categorisation skills. Students are led to a deeper understanding of key words as they examine the similarities and differences of related words through analysing the features or characteristics of word concepts. When students use SFA, they build conceptual knowledge of words and discover related words within a category, an important aspect of deepening their comprehension of words. These described language learning skills were activated and practised while students were compiling the dictionary wiki, as shown in the reflections of students on the process in the next section.

The main research problem concerned the scaffolding of learning content knowledge by home language students. Technology was used in a collaborative way by making use of a wiki to compile an LSP dictionary for Afrikaans language teaching. The research reported in this article was prompted by the following research questions:

- What are the vocabulary selection strategies (inner resources) used by students to define terms in an LSP dictionary in a home language class?

- How do students reflect on the use of external resources and technology via the wiki format in a home language class during the language learning process?

- How do students experience interaction with equal peers when compiling LSP dictionaries collaboratively?

\section{RESEARCH METHODOLOGY}

Qualitative data were gathered by means of a questionnaire after completion of the wiki. A structured questionnaire for critical reflection by students was used as a data collection instrument. The questionnaire is attached as Addendum A, and a translation for the purpose of the article is attached as Addendum B.

Hambleton (in Coe, Waring, Hedges \& Arthur, 2017: 235) views questionnaires among the most common means used by researchers to compile data for their studies as they may be tailored exactly to the needs the researcher. Critical reflection by students on the use of a wiki was used to derive meaning and was interpreted with regard to the students' understanding of the process of learning with the integrated use of technology in relation to Afrikaans language teaching in the home language class.

\section{Participants}

BEd 3 intermediate phase students took part in the project. The Afrikaans teaching module had 33 students enrolled, all of whom had Afrikaans as their L1. The group consisted of four male and 29 female students, all between the ages of 21 and 22 years old. A total of 28 students responded to the questionnaires. As students took part anonymously, further biographic data about respondents were not collected.

\section{Data collection}


A questionnaire was given to students after the completion of the dictionary wiki for them to reflect on their learning experience. It could be described as a self-report data collection instrument through which each respondent filled out a part of a research study and thereby provided rich descriptive information. The questions assessed the students' views concerning the task that they completed in compiling the dictionary wiki.

The questionnaire consisted of nine questions. The first question was used to determine the difficulty of the task; the second question concerned the selection of lemmas; the third question concerned the perception of the difficulty of selecting lemmas; the fourth question dealt with strategies used to define terms; and the fifth to ninth questions focused on the use of technology in the classroom, with possible recommendations for future students about completing the task. The majority of questions were open-ended for the purpose of gathering rich data from participants.

Ethical clearance for conducting the research had been obtained from the University of Stellenbosch under the MobiLex project. Participants were handed a questionnaire by the researcher's assistant to complete at home, voluntarily. Students were under no obligation to complete the questionnaire. They were informed that it was not obligatory, that they had a choice not to participate and that questionnaires were to be completed anonymously. Students who wished to hand in the questionnaire had the opportunity to leave it in the researcher's locked post box at the university, during a span of two weeks.

\section{DATA PRESENTATION OF STUDENTS' REFLECTIONS ON THE COMPILATION OF A DICTIONARY WIKI}

Data were analysed according to thematic analysis, as described in the sections on the research problem and research methodology in this paper. Three themes are discussed, namely, vocabulary selection strategies, the use of outer resources and technology, as well as interaction with equal peers. With reference to the proposed scaffolding model in Figure 1, the three themes fall under quadrants 2,3 and 4 respectively. The way the data informed the proposed scaffolding model in Figure 1 is also indicated.

\section{Vocabulary selection strategies}

Strategies used to define terms to develop academic literacy, as described by Antonacci and O'Callaghan (2011: 12), were mentioned in the reflection sheet. Respondents had to reflect on all the strategies employed during the definition of their terms. The three strategies used most widely by respondents, in order of popularity, were contextual redefinition, wordconsciousness and semantic feature analysis. The least used strategy was that of semantic mapping. This finding was surprising, since most language teachers are aware of this strategy. Quadrant 4 (inner resources) in the scaffolding model in Figure 1 was informed by the data mentioned here, as vocabulary selection strategies could be viewed as part of students' inner resources.

\section{The use of outer resources and technology}

Regarding the selection of lemmas, respondents reported that they found terms in different outside resources, namely coursework (written terms in module notes and PowerPoint slides; terms used orally in lectures), school language curriculum documents (CAPS), textbooks, dictionaries and terms on the internet. One student recorded that she kept a journal of difficult 
terms. Quadrant 3 (outer resources) in the scaffolding model in Figure 1 was informed by the abovementioned data.

Gouws (2016: 121) describes the new generation of dictionary users as Generation Z (born in the digital age, 2011). Although many of them are still at school, they would make up the largest part of the workforce within a decade. This is a generation that grew up with the internet, and they cannot picture their lives without it. According to Urban Dictionary (s.a.):

This generation is very networked with social networks and many means of communication and means of entertainment at their fingertips such as Cell Phones, iPod, Facebook, YouTube and IM. Digital networking and sharing is common and many have not known a time without the internet...

Pre-service teachers would probably end up teaching some Generation $\mathrm{Z}$ learners in their class and would therefore need to be acquainted with the use of technology themselves. It is then beneficial to them to have been exposed to learning by means of technology, in this case a wiki.

There were many positive comments on the use of the wiki medium, as can be seen from the following comments made by students:

- It was interesting to read all the words created by my fellow students.

- The electronic side was interesting, because everybody had to adapt and think about words, because we could not all use the same words.

- It was a very interesting and exciting process, but frustrating as well since many students chose unusual words and you were then forced to do the same.

- It was enjoyable, but I think it would even be more enjoyable to keep your words secret until the end of the process.

- It was a very good learning experience, as I have not done something similar at all.

- It was very easy and convenient, as you had the assignment, as well as all the information at your disposal.

- It made the assignment easier, as I could keep track of all the words uploaded on the wiki.

The abovementioned feedback by respondents resonated by words with positive connotations, such as interesting, exciting, enjoyable, very good learning experience, easy and convenient. These are all words to describe a positive learning experience.

Some of the answers reported on the use of technology (i.e., the electronic version of the assignment) were negative. Four of the typical responses to the question follow:

- It was challenging and frustrating, as only one person at a time could work on the wiki and I had to wait a long time to get a chance to work on the programme, and by then some of my lemma choices had already been included.

- Sometimes confusing, as it was difficult to read through all the words to make sure that you do not duplicate the words.

- I had problems with the format of the wiki.

- It was easy to read what other students put on the wiki, but not so easy to upload the words. 
The first response was on the electronic nature of the wiki as it was only possible for one person to work on it at a time. The second response was more on the nature of a wiki, as a resource available to the whole class. The final two responses show that not all students possessed the necessary technological skills to work on the wiki medium. If they do not upgrade their skills, they could face challenges teaching Generation Z.

\section{Interaction with equal peers}

Regarding the collaborative nature of the assignment, respondents reacted very positively to the notion of collaborating with their equals. Respondents said that they could learn something from the experience, as depicted by the following answers:

- Very functional, as I was reading words and their meanings on the wiki, I got to learn new words and their meanings.

- Yes, I could adapt or change my words if I had the same word as my classmates and extended my Afrikaans subject vocabulary.

- Yes, there were words that I did not know, but by reading the explanations on the wiki, I broadened my knowledge on the subject.

- I could improve myself.

Since one of the objectives of the task-based dictionary project was to improve the academic and concept literacy of Afrikaans language teaching, it could be said that students felt that they had a positive learning experience and learnt from their peers. Meaning was constructed in a socially cultured way for students.

The second objective of the project was to promote long-term retention of subject vocabulary, as is substantiated by the following answers:

- Yes, I could do revision of terms.

- Very effective. One could get a perspective of all the subject terms in Afrikaans.

Interaction with peers also supplied supported learning opportunities, as deduced from the following comments:

- It helped a lot to see what the others did and then I could follow their example.

- It was very interesting to see all the new words that my fellow-students created.

- It helped me to see what other people did, because I learned new words and their meanings.

Quadrant 2 in the scaffolding model in Figure 1 was informed by the data mentioned with regard to learning collaboratively by scaffolding knowledge gained from peers. Students enjoyed working collaboratively; they found the learning experience enjoyable and worthwhile. They agreed that the method was very effective for learning subject vocabulary, which was the purpose of the assignment. 


\section{CONCLUSION}

Language learning and technology were integrated in a task-based assignment for learning in the home language class by means of the construction of online dictionaries. Working together collaboratively with peers was motivation for learning and extending subject vocabulary.

The researcher acknowledges the limitations of the study, as the compilation of a dictionary wiki was done for three years consecutively, but only one group was asked to provide feedback on the task. The group consisted of 33 members, and 28 members responded to the call for feedback. This was a small group, and the recommendations for further study are to include larger groups as well as to include more than one language, in order to produce a bilingual or a multilingual dictionary, using technology.

Possible recommendations for future students completing the task-based assignment reflect the positive mindset of respondents regarding this assignment. Academically inspiring recommendations, such as the following, revealed the significance, worth and meaning the task had for the respondents:

- Do not only select easy words, but rather select more difficult words, so that you could extend your subject knowledge and subject terminology.

- Do research and make use of new words that add meaning to education.

- Make a list of words that are unknown to you and look them up in the dictionary.

It is clear from the feedback from students that working collaboratively, integrated with the use of technology, made a difference to the extension of their subject vocabulary in the learning of their home language. The PCK of pre-service teachers was developed by creating an awareness of dictionaries as resources to be integrated for the content-based development of vocabulary. Experiential learning would hopefully give them the confidence to make use of collaborative language learning tools in their own classrooms in the future, acknowledging the pedagogical purpose of lexicography.

\section{REFERENCES}

ANTONACCI, PA \& CM O’CALLAGHAN. 2011. Developing content area literacy. Los Angeles, CA: Sage.

ASLAN, E. 2016. A study on the use of mobile dictionaries in vocabulary teaching. Journal of Language and Linguistic Studies, 12(1):1-8.

CARSTENS, A. 2016. Designing linguistically flexible scaffolding for subject-specific academic literacy interventions. Per Linguam, 32(3):1-12.

COE, R, M WARING, LV HEDGES \& J ARTHUR. 2017. Research methods and methodologies in education. Los Angeles, CA: Sage.

DEPARTMENT OF BASIC EDUCATION. 2011. Curriculum and assessment policy statement Afrikaans home language. Pretoria: Government Printers.

FOSNOT, CT. 1996. Constructivism: Theory, perspectives and practice. New York: Teachers College Press. 
GOUWS, RH. 2016. Op pad na "n omvattende woordeboekkultuur in die digitale era [Towards a comprehensive dictionary culture in the digital era]. Lexikos, 26:103123.

HEIMLICH, JE \& SD PITTELMAN. 1986. Semantic mapping: Classroom applications. Newark, DE: International Reading Association.

LEW, R. 2010. Multimodal lexicography: The representation of meaning in electronic dictionaries. Lexikos, 20:290-306.

NKOMO, D \& M MADIBA. 2011. The compilation of multilingual concept literacy glossaries at the University of Cape Town: A lexicographical function theoretical approach. Lexikos, 21:144-168.

RICHARDSON, V (Ed.). 2001. Handbook of research on teaching. Washington, DC: American Educational Research Association.

RICHARDSON, V \& P PLACIER. 2001. Teacher change. In V Richardson (Ed.), Handbook of research on teaching. Washington, DC: American Educational Research Association. 905-947.

TALJARD, E. 2015. Collocations and grammatical patterns in an online multiterm term bank. Lexikos, 25:387-402.

SHULMAN, LS. 1986. Those who understand: Knowledge growth in teaching. Educational Researcher, 15:4-14.

SCHULMAN, LS. 1987. Knowledge and teaching: Foundations of the new reform. Harvard Educational Review, 57(1):1-22.

SIMS, RR \& SJ SIMS (Eds). 1995. The importance of learning styles: Understanding the implications for learning, course design and education. London: Greenwood Press.

PUNCH, KF \& A OANCEA. 2014. Introduction to research methods in education. London: Sage.

Urban Dictionary. 2019. [Online]. Available: https://www.urbandictionary.com/define.php?term=Generation\%20Z [2019, September 16].

VAN LIER, L. 2004. The ecology and semiotics of language learning. Dordrecht: Kluwer Academie.

VAN DER MERWE, M.F. 2009. Die opvoedkundige waarde van woordeboeke: Voorstelle vir woordeboekonderrig in Suid-Afrika, Lexikos, 19: 297-313.

VAN DER MERWE, M.F. \& C.A. AMERICA. 2017. Die rol van ' $n$ veeltalige selfoonwoordeboek in die ontwikkeling van konsepgeletterdheid vir onderwysstudente in die ekonomiese en bestuurswetenskappe. Litnet Akademies, 14 (1); 213-243.

VAN DER MERWE, M.F. 2017. Dictionaries a wealth of knowledge? Perceptions of multilingual Education students on mobile LSP dictionaries. Journal for Language Teaching, 51 (2): 59-83.

VAN DER MERWE, M.F. \& K.HORN. 2018. Mobile Concepts in a Mobile Environment: Historical terms in LSP Lexicography. Yesterday \& Today, 19: 17-34.

VYGOTSKY, LS. 1978. Mind in society. Cambridge, MA: Harvard University Press.

\section{BIOGRAPHICAL NOTE}

Michele van der Merwe is a senior lecturer at the University of Stellenbosch where she lectures Afrikaans in the Curriculum Studies Department in the Faculty of Education. Her research foci include lexicography, lexicography in education, as well as language teaching at school as well as university level. Her fields of interest lie in the pedagogical lexicography, as well as LSP dictionaries. 


\section{Addendum A}

\section{Refleksie oor die opstel van ‘n woordeboekwiki}

1. Moeilikheidsgraad van die taak: hoe moeilik was die taak op ' $n$ skaal van 1-5 (1 = maklik $-5=$ moeilik)?

2. Hoe het jy besluit watter woorde om te definieer? Verskaf voorbeelde asb.

3. Merk op jou teks die moeilikheidsgraad van die woorde wat jy gekies het op ' $\mathrm{n}$ skaal van $1-5$.

4. Watter strategie het jy gevolg om die woorde te definieer? Merk die strategieë verskaf.

\begin{tabular}{|l|l|}
\hline Woordebewustheid & \\
\hline Breinkaart met semanties verwante terme & \\
\hline Konteksleidrade & \\
\hline Semantiese analise van terme & \\
\hline
\end{tabular}

5. Hoe het jy die elektroniese sy van die taak ervaar?

6. Was dit funksioneel om te lees wat jou klasmaats op die wiki skryf?

7. Verkies jy om die taak elektronies te doen of om dit in hardekopie in te handig?

8. Motiveer asb. jou antwoord.

9. Watter aanbevelings sal jy aan ander studente maak om die taak suksesvol te beantwoord? 


\section{Addendum B: Translation of Addendum A \\ Reflection on the compilation of an LSP dictionary by means of a wiki}

1. Level of difficulty: how difficult was the task on a level of 1-5 ( $1=$ easy $-5=$ difficult $)$ ?

2. How did you decide on which words to define?

3. Mark on your text the level of difficulty of the terms that you chose to define on a scale of $1-5$.

4. What is the strategy that you followed to define the terms?

5. How did you find the electronic version of the task?

6. Was it functional to read what your peers wrote on the wiki?

7. Do you prefer to do the assignment electronically or in hard copy?

8. Please motivate your answer.

9. What recommendations would you make to your peers in order to complete the task successfully? 